\title{
Związek morfologii wybranych osuwisk z budową geologiczną Karpat i zapadliska przedkarpackiego w świetle analiz numerycznego modelu terenu
}

\author{
Marcin Wódka ${ }^{1}$
}

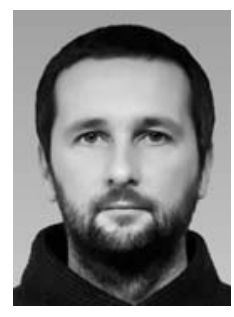

The relationship between the selected landslide morphology and the geologic setting of the Carpathians and the Carpathian Foredeep based on the digital terrain model. Prz. Geol., 66: 115-122; doi: 10.7306/2019.3.

A b s tr a c t. This article presents the results of digital terrain model analysis and field observations related to occurrence of characteristic forms in landslide surface that may indicate the geological setting. Based on these observations, three characteristic structures were selected occurring on many landslides in the Carpathian Mountains and the Carpathian Foredeep. The former are the wrinkle structures visible on the digital terrain model associated with movement along the bedded surface. The other are the streak structures linked to the occurrence of gravels and sands on the clays. The third mogul type structures are related to cylindrical sliding surfaces formed in clay.

Keywords: landslide, digital terrain model, Outer Carpatians, Carpathian Foredeep

Ścisły związek osuwisk z budową geologiczną podłoża znany jest nie od dziś. Zarówno uskoki tektoniczne, jak litologia i układ warstw podłoża wpływają na rzeźbę osuwisk (m.in. Bober, 1984; Hutchinson, 1995; Dikau i in., 1996; Wójcik, Zimnal, 1996; Zabuski i in., 1999; Margielewski, 2001; Sikora, 2015). Często wyraźne skarpy główne, a także i wtórne, odzwierciedlają przebieg uskoków, a skarpy główne osuwisk konsekwentnych, nawet tych, w których zaznacza się bogata rzeźba wewnątrzosuwiskowa, są zwykle niskie. Koluwia płytkich osuwisk we fliszu cienkoławicowym składają się głównie z roztartych łupków i iłów, dlatego ich rzeźba wewnątrzosuwiskowa bywa bogata, ale jest bardziej podatna na zrównanie w wyniku erozji czy też działalności człowieka. Natomiast w koluwiach osuwisk założonych w piaskowcach gruboławicowych występuja głównie gliny z rumoszem i blokami piaskowców oraz zrotowane pakiety skalne - zatem formy osuwiskowe mogą być wielkoskalowe i znacznie odporniejsze na wyrównanie, przez co wyraźne nawet na starych i nieaktywnych osuwiskach (Oszczypko, Wójcik, 1984). Wiadomo też, że osuwiska typu spływu rynnowego tworzą się głównie w skałach jednorodnych, takich jak lessy czy iły.

Granice osuwisk oraz ich wewnętrznych form można wyznaczać za pomocą interpretacji zdjęć lotniczych, map topograficznych oraz wysokościowych modeli terenu, ale podstawą do stwierdzenia osuwiska na danym obszarze są obserwacje terenowe. Wielu badaczy zwraca uwagę na błędy wynikające z interpretacji osuwisk jedynie na podstawie numerycznego modelu terenu, bez wizji terenowej (m.in. Wojciechowski i in., 2015; Kroh i in., 2015). Niemniej jednak analizy wysokościowych modeli terenu znacznie ułatwiają i przyspieszają prace kartograficzne i są niezwykle przydatne do określania subtelnych oraz wielkoskalowych form osuwiskowych (Borkowski i in., 2011; Wojciechowski i in., 2012; Perski i in., 2013; Wójcik i in., 2013; Migoń i in., 2014; Kamiński, Nitychoruk, 2015; Kaczorowski, 2017).

Najdokładniejszą i najszybszą metodą pozyskiwania danych potrzebnych do utworzenia numerycznego modelu terenu jest lotniczy skaning laserowy (Wójcik i in., 2013).
Dane, uzyskane w postaci tzw. chmury punktów, są poddawane klasyfikacji i filtracji, aby jak najlepiej odzwierciedlały rzeźbę terenu.

Artykuł jest wynikiem wstępnych badań nad morfologią osuwisk w zależności od budowy geologicznej ich podłoża. Jego celem jest wskazanie charakterystycznych i powtarzalnych powierzchniowych form osuwiskowych, zaznaczających się na numerycznym modelu terenu i określenie ich związku z budową geologiczną terenu.

\section{OBSZAR BADAŃ}

Do badań wybrano 7 osuwisk: 2 osuwiska w jednostce śląskiej Karpat fliszowych - jedno na stokach góry Leskowiec, a drugie na Chrobaczej Łące - oraz 5 osuwisk, które rozwinęły się w zapadlisku przedkarpackim, w miejscowościach: Skrzyszów, Krostoszowice, Łazy, Brzeźnica oraz Gołkowice (ryc. 1). Osuwiska te charakteryzują się szczególnymi i powtarzalnymi cechami morfologicznymi, zaznaczającymi się na numerycznym modelu terenu i leżą w rejonach o zróżnicowanej budowie geologicznej.

Osuwiska w Skrzyszowie, Krostoszowicach i Gołkowicach wykształciły się w utworach zachodniego obrzeża zapadliska przedkarpackiego. $\mathrm{W}$ ich podłożu występują osady karbonu górnego (namur-westfal), na których zalegaja ilaste osady środkowomioceńskie (baden-sarmat) o miąższości ponad $600 \mathrm{~m}$ (Wójcik, 1999). Są to szare iły margliste z wkładkami piaskowców i łupków warstw skawińskich oraz wyżejległe warstwy grabowieckie. W rejonie badań na powierzchni terenu występują utwory czwartorzędowe o miąższości od kilku do kilkudziesięciu metrów, reprezentowane przez piaski, żwiry oraz lessy.

Osuwiska w Brzeźnicy i Łazach powstały w zapadlisku przedkarpackim, na północ od nasunięcia Karpat zewnętrznych. Pierwsze z nich rozwinęło się w pasie sfałdowanych osadów miocenu jednostki zgłobickiej, a drugie - w autochtonicznych utworach miocenu (Kopciowski $\mathrm{i}$ in., 2014). Miażzzość środkowomioceńskich (badeńskich) osadów wypełniających zapadlisko przedkarpackie w tym rejonie wynosi od 800 do ponad $1000 \mathrm{~m}$ (Poborski, Skoczylas-Ciszewska, 1963). Na ich profil składają się serie

\footnotetext{
${ }^{1}$ Państwowy Instytut Geologiczny - Państwowy Instytut Badawczy, ul. Skrzatów 1, 31-560 Kraków; mwod@pgi.gov.pl
} 


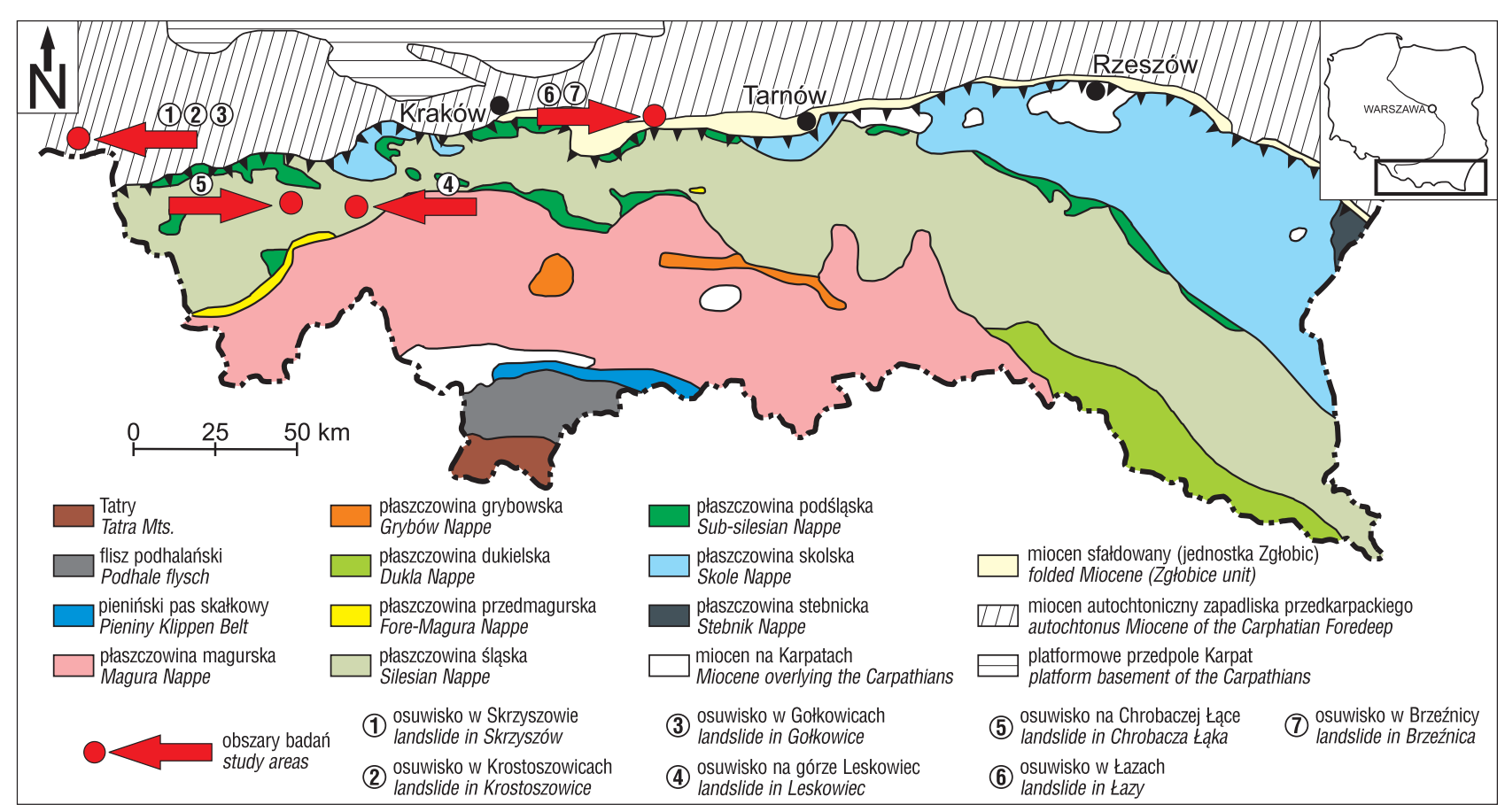

Ryc. 1. Obszary badań na tle mapy geologicznej Karpat (wg Oszczypki 2006, zmieniona)

Fig. 1. Location of study area on the geological sketch of the Polish Carpathians (after Oszczypko 2006, modified)

gipsowo-ilasto-anhydrytowe, w których lokalnie występują złoża soli kamiennej. Ponad osadami solonośnymi znajdują się iły i iłołupki margliste warstw chodenickich oraz młodsze iły z przewarstwieniami piasków lub słabo zwięzłych piaskowców warstw grabowieckich (Alexandrowicz i in., 1982). Osady te są przykryte utworami czwartorzędowymi o miąższości od kilku do kilkunastu metrów. Należą do nich m.in. piaski i żwiry wodnolodowcowe, lessy i mułki oraz piaski i żwiry den dolinnych.

Osuwiska na stokach góry Leskowiec oraz Chrobaczej Łąki uruchomiły się w utworach płaszczowiny śląskiej zewnętrznych Karpat fliszowych. Serię śląską reprezentują tu kompleksy piaskowcowe i piaskowcowo-łupkowe warstw godulskich. Są to pakiety piaskowców gruboławicowych, glaukonitowych i mikowych. Pakiety te rozdzielają cienkie wkładki zielonoszarych łupków ilastych. Występują w nich również wkładki cienkoławicowych piaskowców glaukonitowych (Nescieruk, Wójcik, 2013).

\section{METODYKA}

Dokonano analizy numerycznych modeli terenu (NMT) pod kątem występowania charakterystycznych i powtarzalnych form wewnątrzosuwiskowych. Do badań wytypowano 7 osuwisk i określono ich podstawowe parametry morfometryczne (tab. 1). Modele terenu wygenerowano $\mathrm{z}$ danych ALS pozyskanych z projektu ISOK (Informatyczny System Osłony Kraju), z wykorzystaniem oprogramowania Global Mapper 16. W wyniku obserwacji podjęto próbę klasyfikacji charakterystycznych form zaznaczających się na NMT. Wszystkie te formy zbadano i zweryfikowano w ramach prac terenowych.

Na podstawie obserwacji i pomiarów terenowych oraz Szczegółowej Mapy Geologicznej Polski w skali 1:50 000 (Skoczylas-Ciszewska, Burtan, 1954; Kopciowski i in., 2009; Drozd, Trzepla, 1998; Wójcik, 1999; Nescieruk, Wójcik, 1997; Ryłko, Paul, 2014) określono warunki geo-

Tab. 1. Wybrane parametry morfometryczne badanych osuwisk Table 1. Selected morphometric parameters of landslides examined

\begin{tabular}{|c|c|c|c|c|c|c|c|}
\hline \multirow{2}{*}{$\begin{array}{l}\text { Parametr } \\
\text { Parameter }\end{array}$} & \multicolumn{7}{|c|}{ Osuwisko / Landslide } \\
\hline & $\begin{array}{c}\text { Góra } \\
\text { Leskowiec }\end{array}$ & $\begin{array}{c}\text { Chrobacza } \\
\text { Ląka }\end{array}$ & Skrzyszów & Krostoszowice & Lazy & Brzeźnica & Gołkowice \\
\hline $\begin{array}{l}\text { Powierzchnia [ha] } \\
\text { Area }[\text { ha }]\end{array}$ & 52 & 16 & 0,3 & 4,2 & 36 & 680 & 9 \\
\hline $\begin{array}{l}\text { Długość }[\mathrm{m}] \\
\text { Length }[\mathrm{m}]\end{array}$ & 733 & 586 & 49 & 297 & 592 & 653 & 238 \\
\hline $\begin{array}{l}\text { Szerokość }[\mathrm{m}] \\
\text { Width }[\mathrm{m}]\end{array}$ & 1000 & 303 & 74 & 175 & 691 & 2711 & 487 \\
\hline $\begin{array}{l}\text { Wysokość max. osuwiska [m n.p.m.] } \\
\text { Height maximum [m a.s.1.] }\end{array}$ & 893 & 767 & 262 & 260 & 239 & 290 & 235 \\
\hline $\begin{array}{l}\text { Wysokość min. osuwiska [m n.p.m.] } \\
\text { Height minimum [m a.s.1.] }\end{array}$ & 640 & 585 & 249 & 236 & 210 & 237 & 217 \\
\hline $\begin{array}{l}\text { Max. nachylenie skarpy głównej }\left[{ }^{\circ}\right] \\
\text { Max slope of the scarp }\left[{ }^{\circ}\right]\end{array}$ & 19 & 14 & 35 & 32 & 19 & 11 & 26 \\
\hline $\begin{array}{l}\text { Średnie nachylenie osuwiska }\left[{ }^{\circ}\right] \\
\text { Average slope of the landslide }\left[{ }^{\circ}\right]\end{array}$ & 15 & 17 & 12 & 5 & 4 & 5 & 5 \\
\hline
\end{tabular}


logiczne, tj. litologię koluwiów, litologię podłoża osuwiska, kierunek zapadania warstw w jego najbliższym sąsiedztwie oraz występowanie uskoków i określono związek wybranych wewnątrzosuwiskowych form morfologicznych z budową geologiczną obszaru.

\section{WYNIKI BADAŃ}

W efekcie analizy NMT 7 osuwisk wytypowanych do badań stwierdzono obecność na ich powierzchni charakterystycznych form morfologicznych, które określono jako struktury zmarszczkowe, pręgi oraz muldy. Wyniki przeprowadzonych obserwacji terenowych wykazały, że powstanie tych drugorzędnych form osuwiskowych można wiązać z budową geologiczną obszaru, na którym występują.

\section{Struktury zmarszczkowe}

Struktury zmarszczkowe, zaznaczające się na NMT osuwisk, są formami linijnymi, ułożonymi prostopadle do kierunku zsuwu koluwium i występują w dużym zagęszczeniu. Zwykle przebiegają one przez całą szerokość osuwiska. Struktury te przypominają kształtem zmarszczki i można je porównać do form tworzących się w topniejącym śniegu, który zsuwa się w dół po szybie samochodu.

Struktury zmarszczkowe stwierdzono m.in. na numerycznym modelu terenu 2 osuwisk analizowanych w Beskidzie Małym - osuwiska na południowym stoku góry Leskowiec (ryc. 2) oraz na Chrobaczej Łace (ryc. 3).

Osuwisko na południowym stoku góry Leskowiec, zaznaczone na Mapie osuwisk $i$ terenów zagrożonych ruchami masowymi - MOTZ (Mrozek, Wójcik, 2014), obejmuje obszar leja źródłowego potoku Targoszówka. Rozpoczyna się ono 3-metrową skarpą główną o niewielkim nachyleniu, nieprzekraczającym $20^{\circ}$. W zachodniej części główna skarpa osuwiska jest jeszcze bardziej połoga, przez co słabiej widoczna w terenie. Wschodnia granica osuwiska jest wyraźniejsza ze względu na wysoka, blisko 9-metrową skarpę boczną, najprawdopodobniej związaną z uskokiem o przebiegu NW-SE. Osuwisko to ma charakterystyczną rzeźbę wewnątrzosuwiskową, w której zaznaczają się liczne, prawie prostolinijne struktury są to skarpy wtórne o wysokości od $1 \mathrm{~m}$ do $10 \mathrm{~m}$ oraz progi akumulacyjne. Formy te występują w dużym zagęszczeniu; układają się prostopadle do kierunku zsuwu, a ich rozciagłość dochodzi do $300 \mathrm{~m}$. Obserwowane z góry na numerycznym modelu terenu kształtem przypominaja zmarszczki i są nieznacznie sfałdowane. Oprócz zmarszczek na powierzchni osuwiska zarejestrowano też bezodpływowe zagłębienia terenu i rowy rozpadlinowe występujące poniżej skarp wtórnych. Osuwisko to rozwinęło się w gruboławicowych piaskowcach warstw godulskich środkowych, w których występują pakiety łupków ilastych o miąższości do $20 \mathrm{~cm}$ (Nescieruk, Wójcik, 2013). Warstwy te zalegają konsekwentnie względem stoku.

Osuwisko na Chrobaczej Łące (ryc. 3) - zaznaczone na SMGP (Nescieruk, Wójcik, 1997) i na MOTZ (Wieczorek, Stoiński, 2009) - powstało na stromym, zalesionym stoku, na północny wschód od schroniska. Główna skarpa osuwiska, o wysokości $2 \mathrm{~m}$ i niewielkim nachyleniu, nieprzekraczającym $14^{\circ}$, przechodzi w wyraźniejszą i znacznie wyższą skarpę boczna, wyznaczającą zachodnią krawędź osuwiska. Rzeźba wewnątrzosuwiskowa jest bardzo subtelna, a ze względu na rozmiar form i nachylenie zbocza miejscami słabo widoczna $\mathrm{w}$ terenie, a dobrze czytelna na numerycznym modelu terenu. Na NMT można zauważyć poprzecznie układające się struktury zmarszczkowe o rozciagłości ponad $250 \mathrm{~m}$, czyli przebiegające przez cała szerokość osuwiska (ryc. 3). Osuwisko rozwinęło się w gruboławicowych piaskowcach i łupkach warstw godulskich dolnych, zawierających również wkładki piaskowców o cieńszych ławicach, zalegających konsekwentnie względem stoku (Nescieruk, Wójcik, 2013), co potwierdziły wyniki badań terenowych (ryc. 3).

Oba osuwiska są konsekwentne ( $\mathrm{tj}$. powstały w wyniku przemieszczenia się materiału wzdłuż powierzchni prawie równoległej do powierzchni stoku) i charakteryzują się mało wyraźną skarpą główną o niewielkim nachyleniu.

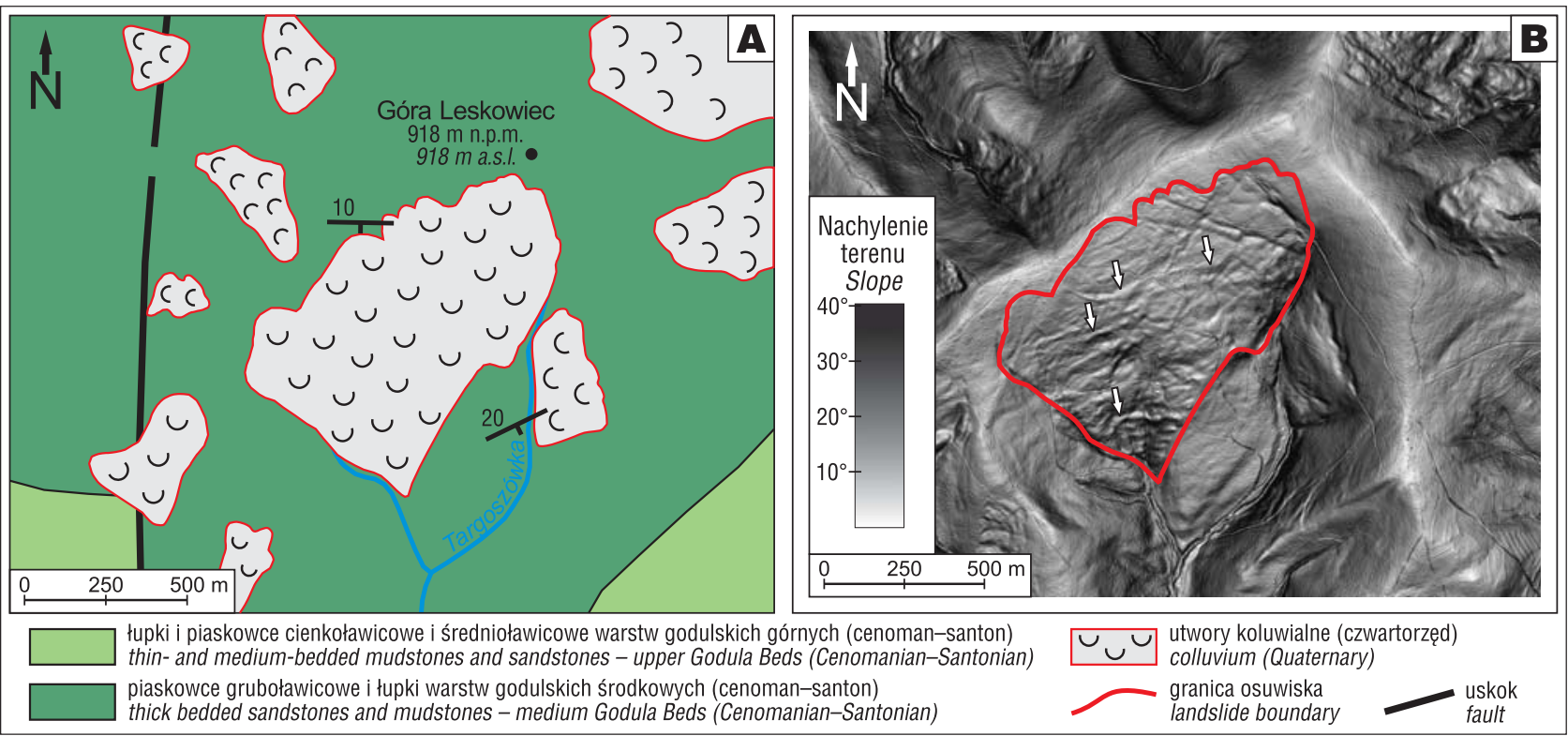

Ryc. 2. Osuwisko na górze Leskowiec z wyraźnymi strukturami zmarszkowymi; A - na podkładzie mapy geologicznej (Ryłko, Paul, 2014); B - na podkładzie numerycznego modelu terenu

Fig. 2. Landslide on Mt. Leskowiec with visible wrinkle structures; A - on the geological map (Ryłko, Paul, 2014); B - on the digital terrain model 
Wewnątrz tych osuwisk występują skarpy wtórne i rowy rozpadlinowe, ograniczone wydłużonymi, przemieszczonymi progami skalnymi, które na modelach terenu wyglądają jak struktury zmarszczkowe. Progi te można wiązać z akumulacją pakietów skał przemieszczających się po stosunkowo płaskiej powierzchni poślizgu i „marszczeniem” się ich na skutek tarcia. Kształt powierzchni poślizgu, przebiegającej zgodnie z płaszczyzną granic litologicznych, sprawia, że miąższość koluwiów w stosunku do rozmiaru tego typu osuwisk nie jest na ogół duża, ale może wzrastać w dolnych partiach stoku (ryc. 4). Podobne struktury zmarszczkowe stwierdzono również w koluwiach osuwisk z innych części Karpat fliszowych, rozwiniętych m.in. na północny wschód od wzgórza Leskowiec, które według autorów arkusza Lacho- wice SMGP (Ryłko, Paul, 2014) należą do osuwisk konsekwentnych. Czasami struktury te są widoczne tylko w części osuwiska, np. w obszarze między skarpą główną a skarpa wtórną, utworzoną powyżej, na skutek rozwoju osuwiska w górę stoku.

\section{Pręgi}

Pręgami nazwano powtarzające się na numerycznych modelach osuwisk podłużne i łukowato wygięte nabrzmienia, naśladujące kształtem krawędź głównej skarpy osuwiska. Na powierzchniach niewielkich osuwisk struktury te są dobrze widoczne w terenie. W przypadku dużych osuwisk, o powierzchni przekraczającej kilka hektarów, a tym

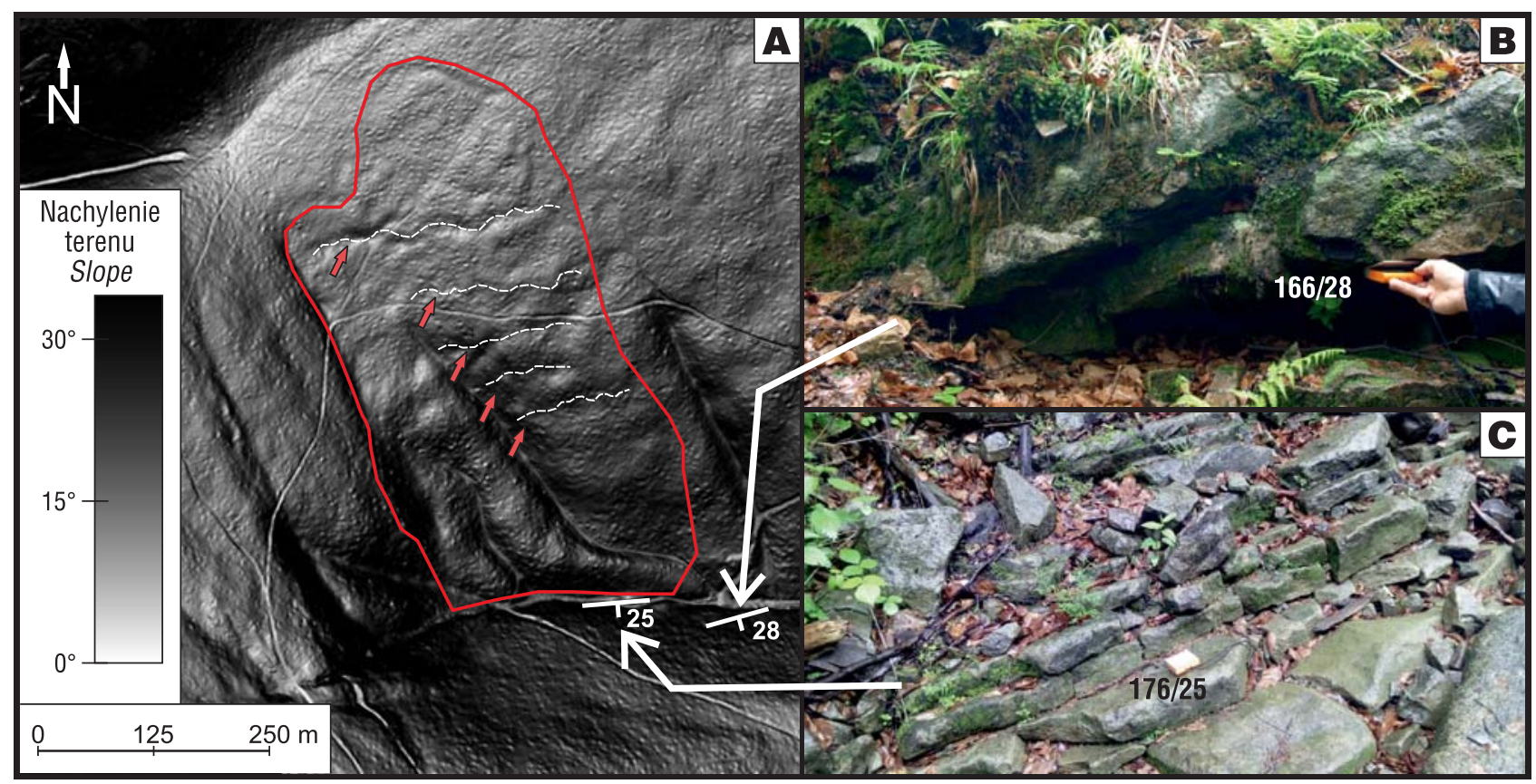

Ryc. 3. Osuwisko na Chrobaczej Łące: A-NMT osuwiska (czerwone strzałki wskazują przebieg subtelnych struktur zmarszczkowych); B i C - wychodnie skał w sąsiedztwie osuwiska, na których wykonano pomiar biegu i upadu warstw

Fig. 3. Landslide on Chrobacza Łąka: A - Digital terrain model (red arrows showing subtle wrinkle structures); B and $\mathbf{C}-$ outcrops where bed strike and dip measurements were made

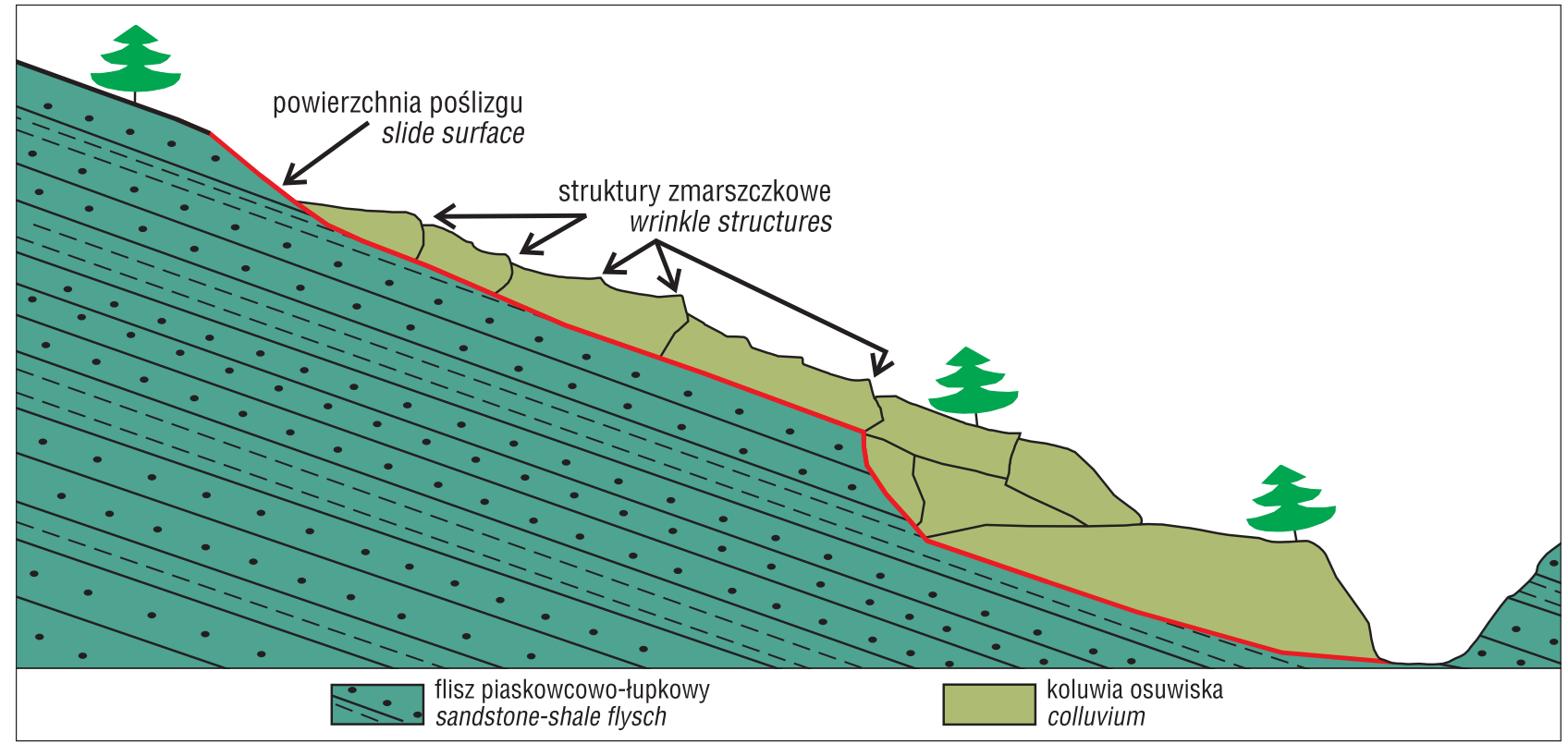

Ryc. 4. Schematyczny przekrój przez osuwisko ze strukturami zmarszczkowymi

Fig. 4. Schematic cross-section through landslide with wrinkle structures 


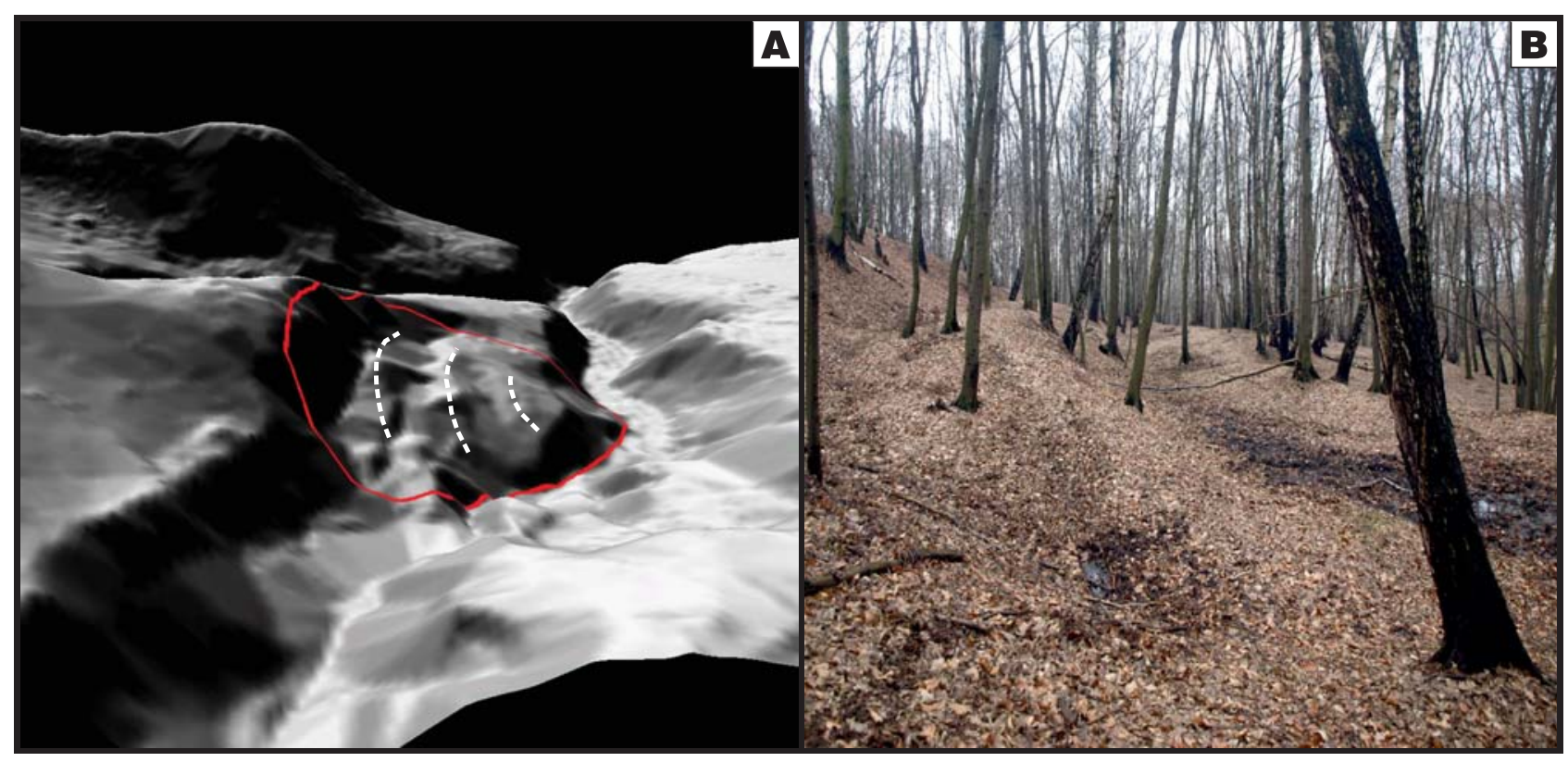

Ryc. 5. Pręgi na powierzchni osuwiska w Skrzyszowie: A - widoczne na modelu 3D wygenerowanym z NMT - przerywane linie wskazują przebieg struktur; $\mathbf{B}$ - obraz pręg w terenie

Fig. 5. Streak structures on landslide in Skrzyszów: A - visible on the 3D model generated from NMT - dashed lines showing structure extent; $\mathbf{B}$ - streak structures in the field

bardziej porośniętych roślinnością, formy te znacznie lepiej zaznaczają się na numerycznym modelu terenu, szczególnie przy skierowaniu podświetlenia prostopadle do stoku.

Pręgi są widoczne na powierzchni niektórych osuwisk w gminie Godów (Wódka, Kamieniarz, 2017). Jednym z nich jest niewielkie osuwisko w miejscowości Skrzyszów, zaznaczone na MOTZ (Wójcik i in., 2017). Osuwisko to rozpoczyna się wyraźną, półkolistą skarpą główną o wysokości do $6 \mathrm{~m}$. Poniżej skarpy występują wydłużone progi akumulacyjne, układające się poprzecznie do kierunku zsuwu koluwium - to właśnie one wyglądają jak pręgi (ryc. 5). Linie tych progów są wyraźnie wygięte, zgodnie z przebiegiem głównej skarpy osuwiska. W zagłębieniach między progami występują podmokłości. Cały obszar osuwiska jest porośnięty lasem. Pnie większości drzew są pochylone i pofalowane (pijany las). Osuwisko rozwinęło się $\mathrm{w}$ ilastych utworach warstw skawińskich (środkowy miocen), na których zalegają piaszczysto-żwirowe osady wodnolodowcowe. Utwory te są widoczne w skarpie głównej, w ścianach progów oraz na powierzchni terenu. Obecność podmokłości wskazuje, że iły mogą występować na niewielkiej głębokości p.p.t.

Niespełna 4 km na NW od Skrzyszowa, w miejscowości Krostoszowice znajduje się znacznie większe osuwisko, na modelu którego zaobserwowano występowanie pręg. Osuwisko to rozpoczyna się stroma, ponad 6-metrową, półkolistą skarpą główną i obejmuje całą długość stoku. Wewnątrz osuwiska występują progi akumulacyjne, poniżej których rozwinęły się skarpy wtórne. Kształt form, ze względu na ich dużą skalę, jest słabo widoczny w terenie, natomiast wyraźnie zaznacza się na numerycznym modelu terenu (ryc. 6), gdzie przyjmuje formę łukowato wygiętych preg. Zarys pręg jest zbliżony do poziomego rzutu skarpy głównej. Osuwisko kończy się czołem o wysokości $4 \mathrm{~m}$. Na podstawie SMGP (Wójcik, 1999) stwierdzono, że osuwisko w Krostoszowicach rozwinęło się w piaskach i żwirach. Biorąc pod uwagę wysokość skarpy głównej, form wewnątrzosuwiskowych oraz czoła, można

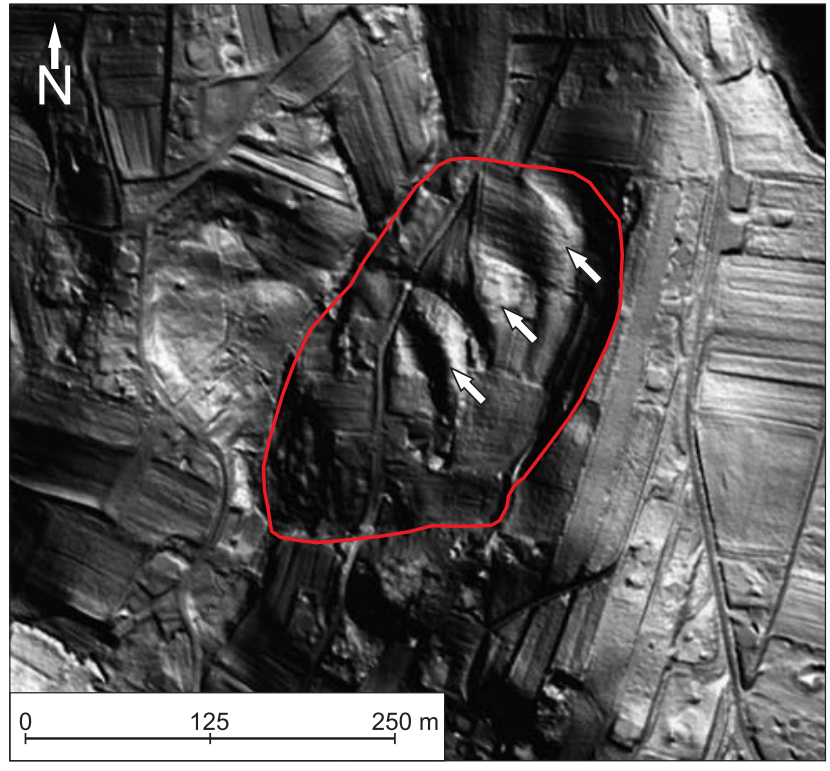

Ryc. 6. Osuwisko w Krostoszowicach na cieniowanym modelu rzeźby terenu przy sztucznym naświetleniu - kąt padania światła $50^{\circ}$, azymut źródła światła $50^{\circ}$. Przebieg pręg wskazują białe strzałki

Fig. 6. Landslide in Krostoszowice on the digital terrain model with artificial lighting. Light direction: altitude $50^{\circ}$, azimuth $50^{\circ}$. Extent of streak structures shown by white arrows

przyjąć, że ruchami masowymi zostały objęte również niżejległe iły mioceńskie.

Charakterystyczne, łukowate pregi stwierdzono również na modelu osuwiska w Łazach. Podobnie jak w Krostoszowicach, ze względu na duże rozmiary, formy te znacznie wyraźniej zaznaczają się na modelu (ryc. 7) niż w terenie. Osuwisko to rozpoczyna się 12-metrową skarpą główną o niewielkim nachyleniu, nie przekraczającym $19^{\circ}$. Poniżej skarpy występuje zagłębienie naśladujące rów rozpadlinowy. Rzeźba wewnątrzosuwiskowa została częściowo zrównana przez działalność rolniczą, mimo tego zachowały się wielkoskalowe, podłużne i łukowato wygięte progi akumu- 
lacyjne, widoczne zwłaszcza w górnej, nie przekształconej rolniczo części osuwiska. Osuwisko kończy się niewyraźnym, zerodowanym czołem. W podłożu osuwiska występują mułowce i iłowce warstw grabowieckich, na których zalegają lessy (Kopciowski i in., 2009). Obecność utworów pylastych potwierdzono w trakcie badań terenowych. Można przyjąć, że między badeńskimi iłami a czwartorzędowymi utworami pylastymi znajdują się piaski i żwiry zlodowacenia południowopolskiego, zwłaszcza że stwierdzono je tuż przy NE granicy osuwiska (Kopciowski i in., 2009).

Pręgi zaobserwowano jedynie w obrębie tych osuwisk, w podłożu których nad utworami ilastymi zalegały osady piaszczysto-żwirowe (ryc. 8). Stwierdzenie takich utworów w skarpie oraz progach niewielkiego osuwiska w Skrzyszowie pozwala przypuszczać, że w wyniku ruchu po cylindrycznych powierzchniach poślizgu, utworzonych w iłach, powstały wypłaszczenia i wyniesienia terenu, które były dobrym miejscem do zahamowania transportu i akumulacji niespoistych utworów piaszczysto-żwirowych, tworzących obecnie pręgi. W gminie Godów osuwiska z zaznaczającymi się w ich rzeźbie pręgami stwierdzono tylko na stokach zbudowanych z iłów i iłowców, przykrytych utworami piaszczysto-żwirowymi (np. osuwiska w Skrzyszowie i Krostoszowicach), podczas gdy na sąsiednich stokach, na których występują gliny, iły lub piaski, nie zaobserwowano struktur przypominających pręgi.

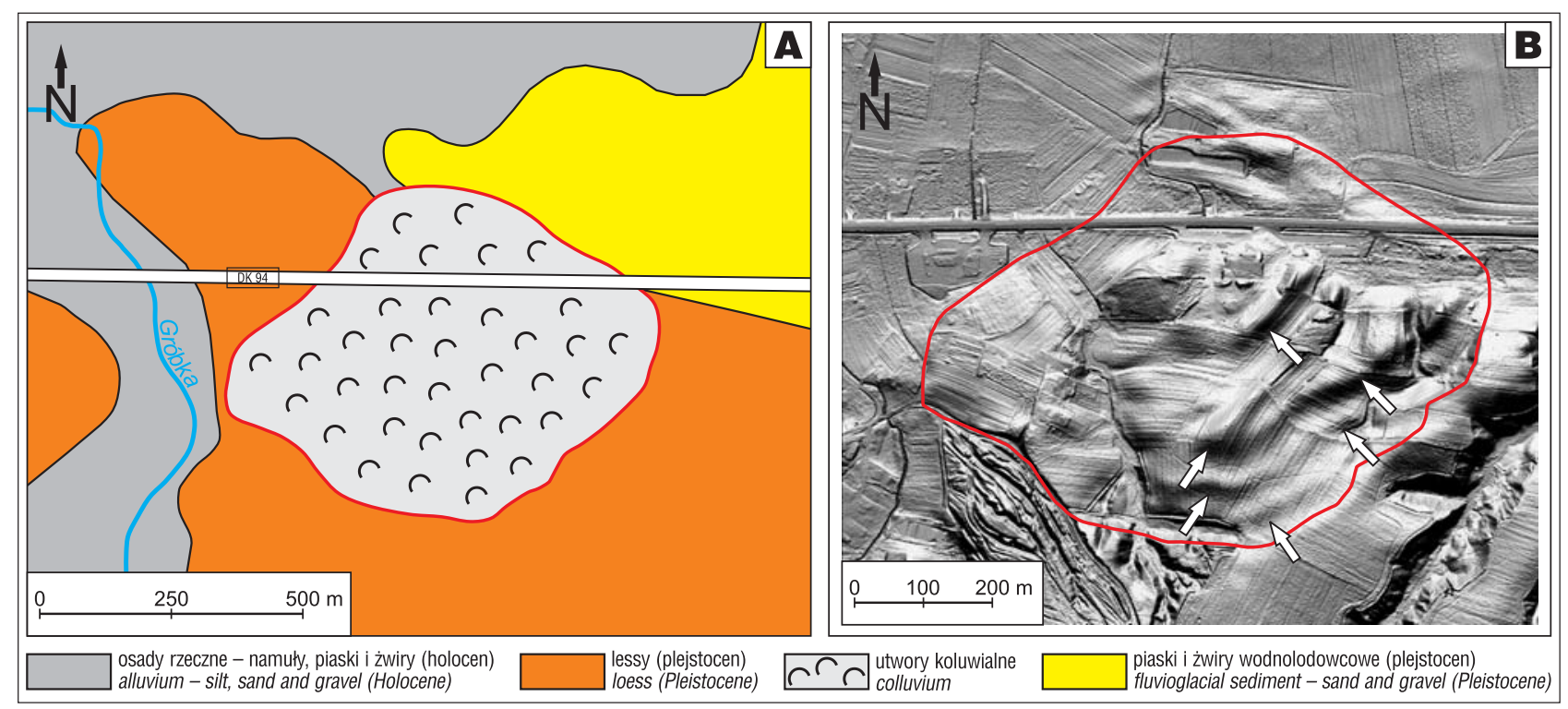

Ryc. 7. Osuwisko w Łazach: A - na podkładzie mapy geologicznej (wg Kopciowskiego i in., 2009); B - na podkładzie cieniowanego modelu rzeźby terenu przy sztucznym oświetleniu - kąt padania światła $42^{\circ}$, azymut źródła światła $350^{\circ}$

Fig. 7. Landslide in Lazy: A - on the geological map (after Kopciowski et al., 2009); B - on the digital terrain model with artificial lighting. Light direction: altitude $42^{\circ}$, azimuth $350^{\circ}$

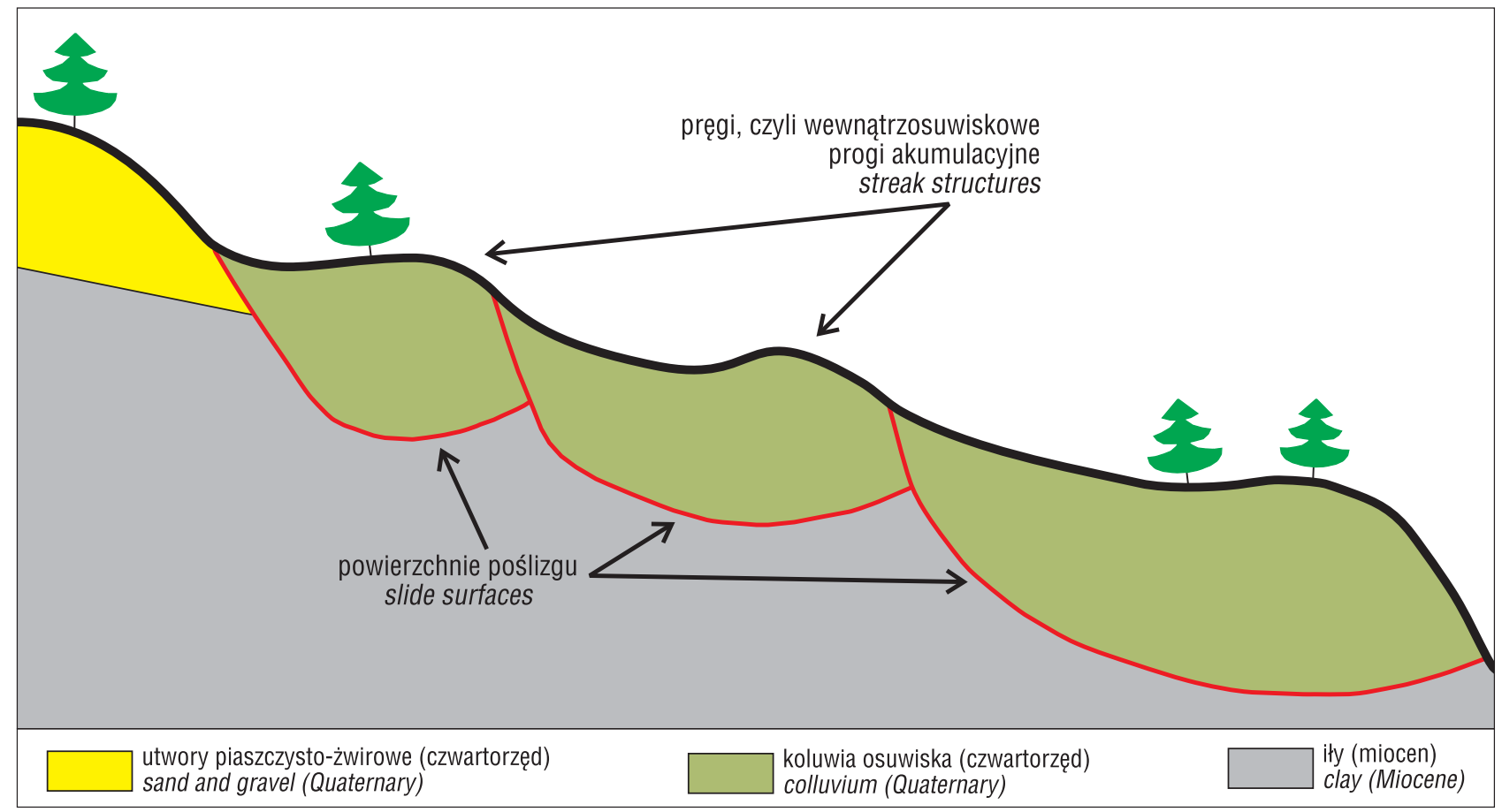

Ryc. 8. Schematyczny przekrój przez osuwisko z pręgami

Fig. 8. Schematic cross-section through the landslide with streak structures 


\section{Muldy}

Muldami nazwano zespoły kolistych wyniesień i bezodpływowych zagłębień, widocznych na numerycznym modelu terenu. Formy te przypominają muldy utworzone w śniegu przez narciarzy, miewają $2-5 \mathrm{~m}$ wysokości, promień od 30 do $200 \mathrm{~m}$ i występują $\mathrm{w}$ dużym zagęszczeniu na powierzchni wielu osuwisk rozwiniętych w zapadlisku przedkarpackim. Płaskie muldy o dużym promieniu są znacznie lepiej widoczne na NMT niż w terenie. Muldy stwierdzono m.in. na powierzchni osuwiska w Brzeźnicy, w gminie Bochnia, oraz osuwiska w Gołkowicach.

Osuwisko w Brzeźnicy rozwinęło się na stoku o niewielkim nachyleniu (wynoszącym do $6^{\circ}$ ) i objęło całą jego długość. Rozpoczyna się ono łagodną skarpą główną, której nachylenie nie przekracza $10^{\circ}$. Znaczna część osuwiska jest użytkowana rolniczo, przez co rzeźba wewnątrzosuwiskowa jest wyrównywana. W obrębie osuwiska nie zaznaczają się wyraźne skarpy wtórne, powszechnie natomiast występują koliste nabrzmienia terenu o dużym zagęszczeniu (ryc. 9). Między nimi znajdują się zagłębienia, z których część jest bezodpływowa. Formy te są dobrze widoczne na NMT, a ze względu na duże rozmiary - mniej czytelne w terenie. Czoło osuwiska jest mocno zerodo- scami zostało całkowicie zerodowane przez potok Piotrówka. Na podstawie arkusza Zebrzydowice SMGP (Wójcik, 1999) można przyjąć, że osuwisko rozwinęło się w piaskach, iłach i glinach zlodowacenia południowopolskiego oraz w środkowomioceńskich iłach i iłach piaszczystych warstw skawińskich.

Geneza muld nie została w pełni wyjaśniona, ale niewątpliwie jest związana $\mathrm{z}$ obecnością utworów ilastych na stokach objętych ruchami masowymi. Występowanie wielu kolistych powierzchni poślizgu w osuwisku powoduje powstanie nabrzmień i zagłębień terenu przypominających muldy. Przemieszczane iły, często w stanie twardoplastycznym lub plastycznym, mają tendencję do tworzenia kolistych, obłych form w postaci nabrzmień terenu.

Muldy stwierdzono wewnątrz osuwisk, które powstały w obszarze zapadliska przedkarpackiego, wypełnionego mioceńskimi utworami ilastymi. Wiele osuwisk rozwiniętych w iłach powstaje na stokach o niewielkim nachyleniu. Nachylenie stoków, na których rozwinęły się badane osuwiska z muldami (poza najmniejszym osuwiskiem w Skrzyszowie), nie przekracza $6^{\circ}$. Powierzchnie poślizgu w iłach, które są utworami jednorodnymi, mają często kształt cylindryczny, co jest wynikiem zsuwu rotacyjnego (Hutchinson, 1995; Dikau i in., 1996; Zabuski i in., 1999).

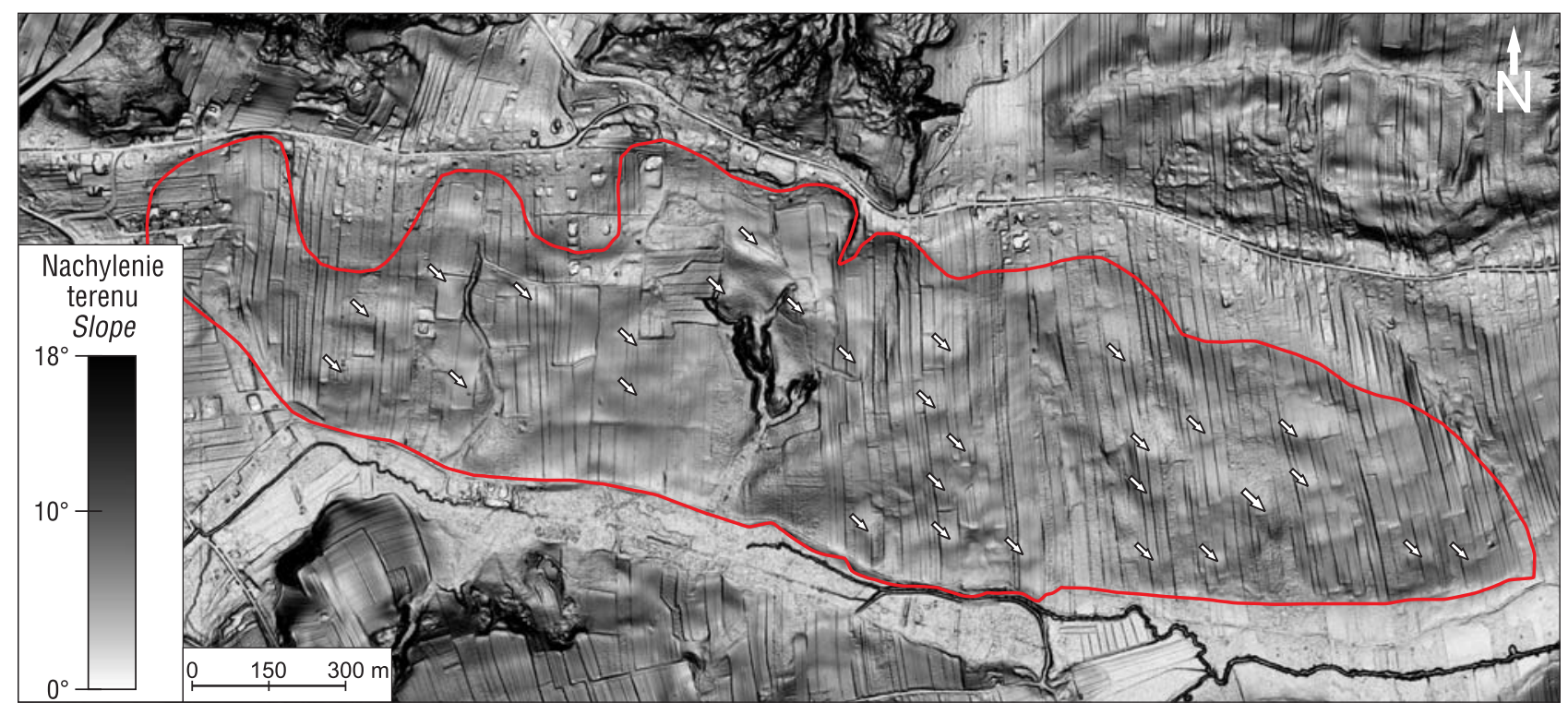

Ryc. 9. Osuwisko w Brzeźnicy na NMT. Białe strzałki wskazują wybrane koliste nabrzmienia terenu (tj. muldy)

Fig. 9. Landslide in Brzeźnica on the digital terrain model. White arrows showing circular terrain convexity

wane przez potok i tylko w niewielu miejscach osiaga wysokość $1 \mathrm{~m}$. Na podstawie arkusza Bochnia SMGP (Skoczylas-Ciszewska, Burtan, 1954; Kopciowski i in., 2009) stwierdzono, że osuwisko rozwinęło się w czwartorzędowych utworach lessopodobnych. Biorąc pod uwagę duży rozmiar osuwiska, obejmuje ono zapewne również mułowce i iłowce warstw chodenickich.

Osuwisko w Gołkowicach - zaznaczone zarówno na SMGP (Wójcik, 1999), jak i na MOTZ (Wójcik i in., 2017) - podobnie jak osuwisko w Brzeźnicy, rozwinęło się na stoku o niewielkim nachyleniu, nie przekraczającym $6^{\circ}$. Główna skarpa osuwiska mierzy $6 \mathrm{~m}$, a miejscami została nadbudowana przez skarpy rolne. Mimo intensywnej działalności rolniczej na powierzchni koluwium zachowała się wyraźna rzeźba wewnątrzosuwiskowa, w postaci wielu rozległych, kolistych nabrzmień i zagłębień terenu (ryc. 10). Osuwisko kończy się 0,5-metrowym czołem, które miej-

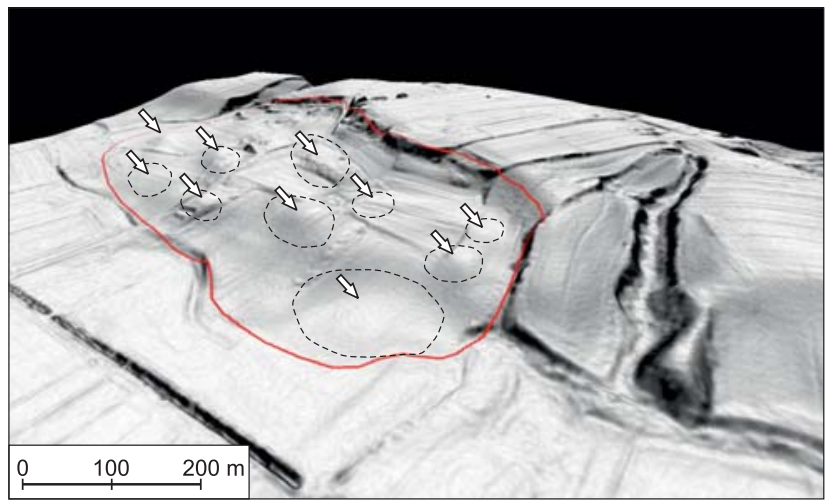

Ryc. 10. Model 3D osuwiska w Gołkowicach, wygenerowany z NMT. Białe strzałki wskazują koliste nabrzmienia terenu

Fig. 10. 3D model of landslide in Gołkowice. White arrows showing circular terrain convexity 
Dolna część takich osuwisk jest wyraźnie wyniesiona wypchnięta. W obrębie jednego osuwiska może występować wiele powierzchni poślizgu oraz liczne zlustrowania związane z przemieszczaniem iłów. Udokumentowano to wieloma otworami m.in. z rejonu Krakowa (Szymonik, Kos, 2013; Różański i in., 2016). Na osuwiskach rozwiniętych w iłach nie obserwowano szczelin, wyraźnych skarp wtórnych oraz wydłużonych, poprzecznych progów akumulacyjnych. Powszechnie natomiast występowały koliste nabrzmienia i zagłębienia terenu.

\section{WNIOSKI}

W wyniku analiz NMT i badań terenowych wybranych 7 karpackich osuwisk stwierdzono w ich rzeźbie charakterystyczne struktury, takie jak zmarszczki, pręgi i muldy. $\mathrm{Na}$ podstawie obecności tych struktur można wyciagać wnioski na temat litologii lub też położenia warstw skalnych, w których rozwinęło się osuwisko. Na przykład prostolinijne struktury zmarszczkowe, widoczne na NMT osuwiska, przebiegające poprzecznie do kierunku ruchu koluwiów, świadczą o tym, że mamy do czynienia z osuwiskiem rozwiniętym na stoku o konsekwentnym zapadaniu warstw. Badane osuwiska, na modelach których zaobserwowano struktury zmarszczkowe, rozwinęły się na piaskowcach gruboławicowych z wkładkami łupków ilastych, które zwykle jako warstwa mniej przepuszczalna są dogodnym miejscem do gromadzenia się wody i powstawania powierzchni poślizgu. Pręgi, czyli obserwowane na modelach podłużne, łukowato wygięte nabrzmienia terenu, kształtem naśladujące skarpę główną, powstają jedynie na powierzchni osuwisk, które rozwinęły się w utworach ilastych, przykrytych przez żwiry i osady piaszczysto-żwirowe. W wyniku ruchów masowych osady te sa akumulowane $\mathrm{w}$ formie łukowatych nabrzmień. Muldy natomiast, tj. koliste progi akumulacyjne, tworzące się w dużej mierze na skutek wypychania materiału skalnego w wyniku przemieszczania koluwiów po cylindrycznych powierzchniach poślizgu, są wskaźnikiem występowania w podłożu osuwiska utworów ilastych. W badanych osuwiskach z muldami nad utworami ilastymi znajdowały się lessy lub piaski i gliny.

Badania sfinansowano z tematu PIG-PIB 61.3506.1703.00.0 - Rozwój charakterystycznych form osuwiskowych w zależności od litologii podtoża.

\section{LITERATURA}

ALEXANDROWICZ S.W., GARLICKI A., RUTKOWSKI J. 1982 Podstawowe jednostki litostratygraficzne miocenu zapadliska przedkarpackiego. Kwart. Geol., 26: 470-471.

BOBER L. 1984 - Rejony osuwiskowe w polskich Karpatach fliszowych i ich związek z budową geologiczną regionu. Biul. Inst. Geol., 340: 115-162. BORKOWSKI A., PERSKI Z., WOJCIECHOWSKI T., JÓZKÓW G., WÓJCIK A. 2011 - Landslides mapping in Rożnów Lake vicinity, Poland using airborne laser scanning data. Acta Geodyn. Geomater., 8, 3 (163): 325-333

DIKAU R., BRUNSDEN D., SCHROTT L., IBSEN M.L. (red.) 1996 Landslide recognition. Identification, Movement and Causes. Willey. DROZD M., TRZEPLA M. 1998 - Szczegółowa Mapa Geologiczna Polski 1:50 000, ark.Zabełków. Nar. Arch. Geol. PIG-PIB, Warszawa. HUTCHINSON J.N. 1995 - Deep-seated mass movements on slopes. Mem. Soc. Geol. It., 50: 147-164.

KACZOROWSKI J. 2017 - Zapis typu ruchu osuwiska w rzeźbie terenu i jego obraz na wysokorozdzielczych numerycznych modelach terenu (NMT) na przykładzie wybranych osuwisk ze wschodniej części Beskidu Niskiego (Karpaty zewnętrzne, Polska). Prz. Geol., 65 (1): 44-52.

KAMIŃSKI M., NITYCHORUK J. 2015 - Cyfrowa analiza fotogrametryczna tempa i charakteru ruchów masowych skarpy rzecznej doliny
Bugu w rejonie Drohiczyna (południowe Podlasie). Prz. Geol., 63 (12/2): 1461-1471.

KOPCIOWSKI R., JUGOWIEC M., LASKOWICZ I. 2009 - Szczegółowa Mapa Geologiczna Polski 1:50 000, ark. Bochnia reambulowany. Nar. Arch. Geol. PIG-PIB, Warszawa.

KROH P., STRUŚ P., WROŃSKA-WAŁACH D., GORCZYCA E., DŁUGOSZ M. 2015 - Porównanie wyników kartowania osuwisk metodami terenowymi oraz opartymi na lotniczym skaningu laserowym. Ogólnopolska Konferencja O! suwisko, Wieliczka 19-22 maja 2015: 39-40.

MARGIELEWSKI W. 2001 - O strukturalnych uwarunkowaniach rozwoju głębokich osuwisk - implikacje dla Karpat fliszowych. Prz. Geol., 49 (6): 515-524.

MIGOŃ P., JANCEWICZ K., KASPRZAK M. 2014 - Zasięg obszarów objętych osuwiskami w Górach Kamiennych (Sudety Środkowe) porównanie map geologicznych i cyfrowego modelu wysokości z danych LIDAR. Prz. Geol., 62 (9): 463-471.

MROZEK T., WÓJCIK A. 2014 - Mapa osuwisk i terenów zagrożonych ruchami masowymi skala 1:10 000. Gmina Stryszawa. Nar. Arch. Geol. PIG-PIB, Warszawa.

NESCIERUK P., WÓJCIK A. 1997 - Szczegółowa Mapa Geologiczna Polski 1:50 000, ark. Bielsko-Biała. Nar. Arch. Geol. PIG-PIB, Warszawa.

NESCIERUK P., WÓJCIK A. 2013 - Objaśnienia do Szczegółowej Mapy Geologicznej Polski 1:50 000, ark. Bielsko-Biała. Nar. Arch. Geol. PIG-PIB, Warszawa.

OSZCZYPKO N. 2006 - Powstanie i rozwój polskiej części zapadliska przedkarpackiego. Prz. Geol., 54: 396-403.

OSZCZYPKO N., WÓJCIK A. 1984 - Utwory czwartorzędowe Beskidu Sądeckiego między Wietrznicą a Jazowskiem. Biul. Inst. Geol., 340: 89-114

PAUL Z., RYŁKO W., TOMAŚ A. 1996 - Zarys budowy geologicznej zachodniej części Karpat polskich (bez utworów czwartorzędowych). Prz. Geol., 44 (5): 469-476.

PERSKI Z., WOJCIECHOWSKI T., WÓJCIK A., NESCIERUK P. 2013 - Techniki naziemne, lotnicze i satelitarne w rozpoznaniu osuwisk. Geotechnika - nowoczesne rozwiązania konstrukcyjno-materiałowo-technologiczne. XXVIII Ogólnopolskie Warsztaty Pracy Projektanta Konstrukcji, Wisła 5-8 marca 2013. T. II: 25-34.

POBORSKI J., SKOCZYLAS-CISZEWSKA K. 1963 - O miocenie w strefie nasunięcia karpackiego w okolicy Wieliczki i Bochni. Rocz. Pol. Tow. Geol., 33 (3): 339-346.

RYŁKO W., PAUL Z. 2014 - Szczegółowa Mapa Geologiczna Polski 1:50 000 arkusz Lachowice. Państw. Inst. Geol. - PIB, Warszawa.

SIKORA R. 2015 - Rola struktury podłoża w powstawaniu osuwisk na przykładzie rejonu Baraniej Góry (Beskid Śląski). Ogólnopolska Konferencja O!suwisko, Wieliczka 19-22 maja 2015. Mat. konf.: 67-68.

SKOCZYLAS-CISZEWSKA K., BURTAN J. 1954 - Szczegółowa Mapa Geologiczna Polski 1:50 000, ark. Bochnia. Nar. Arch. Geol. PIG-PIB, Warszawa.

SZYMONIK L., KOS J. 2013 - Dokumentacja geologiczno-inżynierska dla zadania pn. Stabilizacja osuwiska wraz z remontem drogi - działka nr 174/1 - w miejscowości Chełm w km 2 + 740 - 2+940. PG S.A., Kraków. WIECZOREK D., STOIŃSKI A. 2009 - Mapa osuwisk i terenów zagrożonych ruchami masowymi skala 1:10 000. Gmina Czernichów. Nar. Arch. Geol. PIG-PIB, Warszawa.

WOJCIECHOWKI T., BORKOWSKI A., PERSKI Z., WÓJCIK A. 2012 - Dane z lotniczego skaningu laserowego w badaniu osuwisk - przykład osuwiska w Zbyszycach (Karpaty zewnętrzne). Prz. Geol., 60: 95-102. WOJCIECHOWKI T., PERSKI Z., WÓJCIK A. 2015 - Wykorzystanie wysokościowych danych laserowych w badaniu osuwisk. Ogólnopolska Konferencja O! suwisko, Wieliczka 19-22 maja 2015. Mat. konf.: 79-80. WÓDKA M., KAMIENIARZ S. 2017 - Rozwój osuwisk asekwentnych na obszarach występowania neogeńskich utworów ilastych. 6. Ogólnopolskie Sympozjum Współczesne problemy geologii inżynierskiej w Polsce, Rzeszów 17-20.10.2017. Książka abstraktów: 76-77.

WÓJCIK A. 1999 - Szczegółowa Mapa Geologiczna Polski 1:50 000, ark. Zebrzydowice. Nar. Arch. Geol. PIG-PIB, Warszawa.

WÓJCIK A., ZIMNAL Z. 1996 - Osuwiska wzdłuż doliny Sanu między Bachórzcem a Reczpolem (Karpaty, Pogórze Karpackie). Biul. Państw. Inst. Geol., 374: 77-91.

WÓJCIK A., KAMIENIARZ S., WÓDKA M. 2017 - Mapa osuwisk i terenów zagrożonych ruchami masowymi skala 1:10 000. Gmina Godów. Państw. Inst. Geol. - PIB Warszawa.

WÓJCIK A., WĘŻYK P., WOJCIECHOWSKI T., PERSKI Z., MACZUGA S. 2013 - Geologiczna i geomorfologiczna interpretacja danych $\mathrm{z}$ lotniczego skaningu laserowego (ALS) rejonu Kasprowego Wierchu (Tatry). Prz. Geol., 61 (4): 234-242.

ZABUSKI L., THIEL K., BOBER L. 1999 - Osuwiska we fliszu Karpat polskich. Geologia, modelowanie, obliczenia stateczności. Wyd. IBW PAN.

Praca wpłynęła do redakcji 6.07.2018 r.

Akceptowano do druku 8.01.2019 r. 